\title{
Reconstruction of Judge Authorities on Pretrial in Indonesia Based on Justice Value
}

\author{
Agus Setiawan ${ }^{1 *}$, Mahmutarom ${ }^{2}$, Sri Kusriyah ${ }^{3}$, Alfi Nur Fata ${ }^{4}$, Ade Adriansyah ${ }^{5}$ \\ ${ }^{1}$ Doctorate Student of Faculty of Law Sultan Agung Islamic University Semarang, Indonesia \\ ${ }^{2}$ Faculty of Law Wahid Hasyim University Semarang, Indonesia \\ ${ }^{3}$ Faculty of Law Sultan Agung Islamic University Semarang, Indonesia \\ ${ }^{4}$ Master Student of Faculty of Law Sultan Agung Islamic University Semarang, Indonesia \\ ${ }^{5}$ Master of Notary Student of Faculty of Law Sultan Agung Islamic University Semarang, Indonesia
}

DOI: $\underline{10.36348 / \text { sijlcj.2021.v04i01.003 }}$

| Received: 14.01.2021 | Accepted: 25.01.2021 | Published: 29.01.2021

*Corresponding author: Agus Setiawan

\section{Abstract}

Among many problems that the Indonesian Judiciary practice has encountered, one problem that has been persistently discussed is regarding whether or not can the status of a suspect be used as a pretrial object outside of Article 77 letters (a) and (b) of the Criminal Procedure Code, either through pretrial judge decisions or decisions of the Constitutional Court. From these problems, the author formulated a study on what are the Impact of the Decision of the Judge Adjudicating the Pre-Trial Session outside the Reasons stipulated by law and how the reconstruction of regulations on the authority of judges in adjudicating justice-based pretrial applications can be realized. The research method used is juridical empirical combining doctrinal and non-doctrinal approaches, by operating legal principles and norms to see the normative dimensions of judge's decision, combined with the assumption approach that statutory regulations, including judge's decision, are not under empty space, but exists in a complex reality. The result shows that the legal function established by the Criminal Procedure Code is directed at realizing legal certainty rather than justice so that judges tend to obey conventional procedural law rather than having to be progressive. The limitations of pretrial authority and the lack of courage of judges to protect the rights of suspects have made pretrial institutions less able to protect suspects from possible violations of their juridical rights. To overcome these problems, reconstruction is carried out by clarifying and amending the joint decree (SKB) of the Chairman of the Supreme Court of the Republic of Indonesia and the Chair of KY RI No. .047 / KMA / SKB / IV / 2009 and 02 / SKB / P.KY / IV / 2009 in addition to add one provision between letter b) and letter c) to Article 82 paragraph (1) of the Criminal Procedure Code, and adding 2 (two) paragraphs in Article 1 number 10 in conjunction with Article 77 KUHAP jo. The Decision of the Constitutional Court No.21 / PUUXII / 2015, by means of reasoning or interpreting a contrario (In Contrary) to the provisions of Article 1 point 10 jo. Article 77 KUHAP jo. The existing Constitutional Court Decision No.21 / PUU-XII / 2015.

Keywords: Reconstruction, Judge's Authority, Pretrial, Justice Value.

Copyright (C) 2021 The Author(s): This is an open-access article distributed under the terms of the Creative Commons Attribution 4.0 International License (CC BY-NC 4.0) which permits unrestricted use, distribution, and reproduction in any medium for non-commercial use provided the original author and source are credited.

\section{INTRODUCTION}

Indonesia is a country that is based on law (rechtstaats). Therefore, its judicial power greatly determines the content and strength of the rules of positive law. Judicial power is manifested in the act of examining, assessing, and determining the value of certain human behavior as well as determining the value of concrete situations and resolving problems or conflicts that arise in an impartial manner based on the law as an objective benchmark.

Article 24 paragraphs (1) of the 1945 Constitution states that: "judicial power is an independent power to administer justice in order to uphold law and justice".

The above provisions are the basis for the existence of an independent, neutral and impartial judiciary to carry out a trial that is free from interference by other state powers. In a broader sense, this provision implies that the judiciary as a judiciary, which administers judicial power, cannot and is not allowed to be interfered with by other state powers, both the executive branch, namely the President and his subordinates, as well as the legislative body, namely the Council People's Representative as well as the supervisory institution of the Judicial Commission 
which according to Article 24B paragraph 1 of the 1945 Constitution is given the responsibility to maintain and uphold honor, nobility, and dignity, as well as the behavior of judges.

Article 24 paragraph (2) of the 1945 Constitution, confirms that the implementation of judicial power is carried out by a Supreme Court and judicial bodies under it, namely in general courts, religious courts, military courts, and state administrative courts as well as by a Constitutional Court.

The authority of the judicial power is exercised by judges in the form of guarantees of freedom and independence in conducting trial examinations and decision-making which are only vertically accountable to God Almighty and are accountable horizontally to the public and the state.

The judge's decision will feel very appreciated and have a dignified value if the decision can reflect the sense of legal justice in society and is also a means for people who seek justice to obtain truth and justice. Before a judge decides a case, he will ask his own conscience whether this decision will be fair and beneficial (benefit) for humans or will it lead to more harm.

Judges carry a mandate so that statutory regulations are applied properly and fairly, and if the application of statutory regulations will cause injustice, then the judge must side with justice (moral justice) and override the law or statutory regulations (legal justice). Good law is a law that is in accordance with the law that lives in society (the living law) which of course is also appropriate or is a reflection of the values prevailing in society (social justice). Justice that is meant here is not justice that is formal in nature, but justice that is material/ substantive in accordance with the judge's conscience.

The fact is that legislators only stipulate general regulations, and considerations regarding concrete matters have to be left to the judge. Because legislators are constantly lagging behind (new) social events, it is the judge who has to frequently add to the law.

The law is imperfect. Indeed, it is impossible for the law to completely regulate all activities of human life. There are times when the law is incomplete and there are times when the law is not clear. Even though it is incomplete or unclear the law must be implemented. In the event of a violation of the law, the judge must implement or enforce the law. Judges cannot delay the implementation or enforcement of laws that have been violated. The judge cannot and may not postpone or refuse to issue a decision on the grounds that the law is incomplete or unclear.
Furthermore, Article 10 paragraph (1) of Law Number 48 of 2009 concerning Judicial Powers confirms that:

"The court is prohibited from refusing to examine, hear and decide on a case filed on the pretext that the law does not exist or is unclear, but is obliged to examine and try it".

The provisions of this article give the meaning that the judge is the main organ of a court or the executor of judicial power that is authorized to accept, examine, try a case and subsequently impose a decision for it so that it is obligatory for the judge to find the law in a case even though the legal provisions are not clear or less clear.

Article 5 paragraph (1) of Law Number 48 of 2009, further determines that:

"Judges and constitutional judges are obliged to explore, follow and understand the legal values and a sense of justice that live in the society".

The word "explore" here can be assumed that the law actually already exists, but is still hidden, so that to find it the judge must try it by exploring the legal values that live in the community, then follow it and then understand it so that the decision is in accordance with the sense of justice which lives in society.

It cannot be denied that the existence of Article 77 KUHAP is actually the basis for judges who will hear pretrial cases. However, considering that the provisions in Law Number 8 of 1981 concerning the Criminal Procedure Code (KUHAP) still provide an opportunity for interpretation by judges in interpreting pretrial objects, so that this situation currently causes decisions to be made especially in examining pretrial objects outside of those regulated in the Criminal Procedure Code where the variety of pretrial decisions creates disparities between one pretrial decision and another.

This is because the Judge has the independence in making decisions, so in the same criminal case, the Judge is likely to issue a variety of decisions, including pretrial decisions. The existence of disparities in the verdict was actually as quoted by Hans Kelsen [1] that, "With the denial of the decision, two contradictory decisions were produced, about which one must be true (correct) and the other one is wrong (incorrect, false.)".

This disparity in pretrial decisions brings its own problems in law enforcement in Indonesia. On the one hand, different pretrial decisions are a form of judicial discretion in making decisions, but on the other hand, these pretrial decisions also bring dissatisfaction to the community. Social jealousy also emerged and also negative views by the community on the judiciary, which was later manifested in the form of indifference 
to law enforcement in society. Public trust is decreasing over time in the judiciary, resulting in a condition where the judiciary is no longer trusted or considered as a house of justice for them, or in other words, there is a failure of the criminal justice system. This situation certainly creates inconsistency in judicial decisions and also contradicts the concept of a rule of law adopted by our country where its government is run based on law and is supported by the existence of a judicial institution, namely a judicial institution to enforce the law, what happens if the community no longer believes in law enforcement in Indonesia.

Regarding disparities or differences in the attitudes of judges in imposing crimes, Muladi [2] stated that this can occur in addition to things that come from law, it can also occur due to factors originating from the judge himself, both internal and external which cannot be separated. Because it is already fixated as an attribute of a person called the human equation (human justice) or personality of judge in a broad sense which concerns the influences of social background, religious education, experience and social behavior.

This problem is what urges the author to study it further in a research with the following issues:

1. What is the Impact of the Decision of the Judge Adjudicating the Pre-Trial Session outside the Reasons stipulated by law?

2. How is the reconstruction of the regulation of the judge's authority in adjudicating pretrial based on justice value?

\section{METHOD OF RESEARCH}

The paradigm that is used in the research this is the paradigm of constructivism which is the antithesis of the understanding that lay observation and objectivity in finding a reality or science knowledge [3]. Paradigm also looked at the science of social as an analysis of systematic against Socially Meaningful Action through observation directly and in detail to the problem analyzed.

The research type used in writing this paper is a qualitative research. Writing aims to provide a description of a society or a certain group of people or a description of a symptom or between two or more symptoms.

Approach method used in this research is Empirical-Juridical [4], which is based on the norms of law and the theory of the existing legal enforceability of a law viewpoint as interpretation.

As for the source of research used in this study are:

1. Primary Data, is data obtained from information and information from respondents directly obtained through interviews and literature studies.
2. Secondary Data, is an indirect source that is able to provide additional and reinforcement of research data. Sources of secondary data in the form of: Primary Legal Material and Secondary Legal Materials and Tertiary Legal Material.

In this study, the author use data collection techniques, namely literature study, interviews and documentation where the researcher is a key instrument that is the researcher himself who plans, collects, and interprets the data [5]. Qualitative data analysis is the process of searching for, and systematically compiling data obtained from interviews, field notes and documentation by organizing data into categories, describing it into units, synthesizing, compiling into patterns, selecting important names and what will be studied and make conclusions.

\section{RESEARCH RESULT AND DISCUSSION}

1. Impact of the Decision of the Judge Adjudicating the Pre-Trial Session Outside the Reasons Stipulated By Law

The regulation regarding pretrial objects has been confirmed in Article 1 number 10 KUHAP and Article 77 KUHAP where the full provision of Article 1 point 10 of the Criminal Procedure Code said that pretrial is the authority of the District Court to examine and decide according to the method regulated by this law, concerning:

a. Whether an arrest and or detention is legal or not at the request of the suspect or his family or other party or the suspect's attorney;

b. Whether or not the termination of investigation or prosecution is legal at the request for the sake of upholding law and justice;

c. A request for compensation or rehabilitation by a suspect or his family or other parties on his behalf whose case has not been filed in court;

Furthermore, Article 77 letters (a) and (b) KUHAP confirms the authority of the District Court in examining and making decisions in accordance with the provisions stipulated in the law concerning:

a. Whether or not the arrest, detention, termination of the investigation, or prosecution is legal.

b. Compensation and/ or rehabilitation for a person whose criminal case is terminated at the level of investigation or prosecution.

The method of thinking of judges in common law (judicial) system countries in principle uses the inductive method (thinking from the specific to the general), that is, the decisions are always based on concrete cases or special rules which are then concretized into general rules. The judge's decision acts as a precedent for other judges in similar cases, especially in the ratio decidendi section with the aim that the judge can make decisions more quickly on the case he is currently handling because, In the common 
law system, the judge's decision heavily emphasizes on case law and places a special emphasis through the inductive reasoning approach by adhering to the principle of "the binding force of precedent" (precedent principle) [6]. The inductive approach means that the judge creates a general principle that is obtained from events that occur repeatedly under the same conditions for certain events. Precedent is a systematic form of clear case facts, structure, and organization of the court. When making a decision, each member of the panel of judges provides legal considerations (ratio decidendi) based on an inductive approach.

Whereas from the formulation of the definition of pretrial in article 1 number 10 of the Criminal Procedure Code and the legal norms of regulating pretrial authority as stated in Article 77 of the Criminal Procedure Code, it can be concluded that the existence of a pretrial institution is a means or a place for examining forced attempts by law enforcement officials at the level of investigation and prosecution, forced efforts by the investigation at the level of investigation and by the public prosecutor at the level of prosecution have been carried out according to the provisions and procedures regulated in law or not. Whereas from the formulation of the meaning of Article 1 figure 10 jo. Article 77 jo. Article 82 paragraphs (1) and paragraph (2) can be clearly seen that "whether or not the determination of a suspect is legal" is not included as an object of pretrial because it is not regulated.

The legal considerations should have stopped there and rejected the pretrial petition submitted by the Petitioner, on the basis that no rules were found regarding whether or not the determination of a suspect was a pretrial object as stipulated in article 1 point 10 in conjunction with article 77 in conjunction with article 82 paragraph (1) and paragraph (2) KUHAP.

Legal considerations followed by pretexts as stated in the following considerations indicated that the Judge had forced himself to look for arguments that seemed to have been planned beforehand to arrive at the verdict of granting the Petitioner's petition.

KUHAP as formal law that regulates how to maintain and implement violated material law, should not be interpreted too far from the formulation of the rules as it is different from the legal material which can be interpreted progressively with the assumption of respecting legal values and a sense of justice that exists in society, as regulated in Article 5 Paragraph (1) of Law Number 48/2009 concerning Judicial Power.

The pretrial object is clearly and expressly regulated in Article 77 of the Criminal Procedure Code which is given to the District Court to examine and decide on:

a. Whether or not the arrest, detention, termination of the investigation, or prosecution is legal. b. Compensation and/ or rehabilitation for a person whose criminal case is terminated at the level of investigation and prosecution.

The pretrial judge interpreted "acts of coercion" as: "All actions of the investigator in the investigation process and all actions of the public prosecutor in the process of prosecution constitute acts of coercion because they have placed the label proJustisia (in the name of law)".

The coercive measures provided by the Criminal Procedure Code to investigators and public prosecutors are in the form of arrest, detention, confiscation, search. The provisions regarding pretrial authority, however, do not need to get any interpretation because they are very clear and there is no confusion. The reason for the judge's consideration in this regard cannot be justified. The Determination of a person as a suspect is an administrative process of investigation when sufficient preliminary evidence has been found so this means that it cannot be included in the category of forced efforts. Whereas sufficient preliminary evidence in this stage is the result of the investigator's assessment based on the results of the investigation. The initial evidence that is sufficient at this stage is still in the domain of investigative examination so that it is not at all included in the domain of evidence by the public prosecutor. Furthermore, because the law does not regulate doesn't automatically make the judge able to decline the case on the ground that "the law does not regulate" or "the law does not exist".

The creators of the Criminal Procedure Code firmly emphasized that Article 77 of the Criminal Procedure Code is an object of pretrial because it is implicitly considered an "act of forced effort" which has the potential to violate human rights (HAM). Arrest, detention, including confiscation of evidence, are actions that restrict a person's human rights.

If the arrest, detention, confiscation, and termination of prosecution and prosecution investigations are not carried out according to the procedures stipulated in the Criminal Procedure Code, then this is what is questioned in pretrial as a forced attempt. Therefore, legislators in Article 77 in conjunction with Article 82 Paragraph (3) letter-d and Article 95 of the Criminal Procedure Code do not classify "the determination of a suspect" as a pretrial object because it is considered "not a forced effort" which has the potential to violate human rights (HAM).

Objections to the "determination of the suspect", including insufficient evidence and the application of articles that are not accurately described, clearly, and completely against the criminal act charged (the material requirements of the indictment), objections may be made in the "exception" process by the defendant or his legal advisor after the indictment 
has been read out in court. This is affirmed in Article 143 paragraph (2) of the Criminal Procedure Code, that "the public prosecutor prepares a dated and signed indictment containing: a) full name, place of birth, age or date of birth, sex, nationality, residence, religion, and the occupation of the accused; b) an accurate, clear and complete description of the criminal act charged by stating the time and place where the crime was committed ".

If the exception of the defendant or his legal adviser is accepted because the articles being charged are not clear and accurate or there is an error on the legal subject, the judge in the interim decision rejects the indictment so that the case examination is not continued. It was in this context that the defendant actually questioned his appointment as a suspect, not with the pretrial lawsuit.

For the record, the Draft Amendment to the Criminal Procedure Code regulates that the "commissioner judge or supervisory judge", with the powers, among others, to correct and give approval if a person will be detained, including the determination of a suspect. The commissioner judge examines whether the request for detention or determination of a suspect from the investigator is in accordance with legal provisions or not. However, the presence of commissioner judges in the Draft Amendment to the Criminal Procedure Code and various reports was rejected by the police.

After studying carefully between the regulations in KUHAP and those outside KUHAP, as well as theories related to law enforcement and justice in this writing, the researchers concluded that the weaknesses in the decisions of judges who tried pretrial hearings were seen from the perspective of justice, which includes:

a. The provisions of the Criminal Procedure Code are not in sync, especially Article 3 which adheres to the principle of formal legality which provides independent judicial power in administering the judiciary to uphold law and justice based on Pancasila, for the sake of implementing the State of Law of the Republic of Indonesia as stated in Law No.14 of 1970 which has been amended by Law No.48 of 2009 concerning Judicial Power. As a result, even though the principles in the basic provisions of judicial power have been used as guidelines because what the judge does in deciding pretrial must be in the corridor of the provisions of Article 3 of the Criminal Procedure Code, the pretrial judge's decision as well as to accommodate a substantive sense of justice by some legal experts and the public will still be considered as a strange decision that violated the procedural law;

b. The inconsistency of the rules in the Criminal Procedure Code, which, on one hand, adheres to the 'accusatory" principle where the suspect is no longer considered an object but has been considered a legal subject with dignity whose human rights are upheld, but on the other hand the Criminal Procedure Code still gives discretion to investigators to take other actions according to law who is responsible without clear boundaries as referred to in Article 7 paragraph (1) of the Criminal Procedure Code which has the potential to be very detrimental to the interests of the suspect during the examination stage. The result is when a pretrial judge carefully sees violations of human rights in the determination of a suspect, but because the object of the pretrial is outside the provisions of Article 1 number 10 in conjunction with Article 77 of the Criminal Procedure Code then when the verdict declares the determination of the suspect to be invalid, the right to collect will still be considered to have violated the procedural law even though the independence and obligation of a judge in understanding and exploring the values that grow and live in society seem to deliver the judge as a person of interest.

With this fact, if the State or in this case the Supreme Court does not immediately provide a settlement solution by providing guidance or issuing a Supreme Court regulations (Perma) that technically can unify the opinions of judges, according to researchers this phenomenon is certain that there will be legal uncertainty in the settlement of pretrial cases in Indonesia until then Article 1 number 10 jo. Article 77 KUHAP is subject to amendments by the People's Representative Council (DPR) together with the Government [7]. For this reason, the researcher offers a Reconstruction of the Authority of Judges in Adjudicating Pre-Trial Applications, namely by redesigning the pretrial articles that are in the KUHAP, so that legal certainty is maintained and substantive justice can be realized.

\section{Reconstruction of the Regulation of the Judge's Authority in Adjudicating Pretrial Based On Justice Value}

In order to realize legal rules that are just and humane in enforcing the above pretrial procedural law regulations, pretrial judges must be given the authority to examine the evidence as state guarantees in statutory provisions which are obliged to provide protection, promotion, enforcement, and fulfillment of rights. Human Rights (vide Article 281 paragraph (4) of the 1945 Constitution), so that the State should facilitate suspects in obtaining their rights instead of hindering them when the suspect demands an explanation and disclosure of evidence which makes him a suspect in a pretrial trial.

On the other hand, if pretrial judges are not given the authority to examine the evidence, then this situation can actually harm the interests of the public or the State because with the closure of the State explaining the evidence, this will actually increase the 
potential for the defendant to be released in court only because the prosecutor is incapable. The public prosecutor proves the indictment on the basis of insufficient quality evidence provided by the investigator at the investigation level.

In this context, the law is always in the process of becoming or developing. Law is an institution that continually builds and transforms itself towards a better level of perfection. The quality of this perfection can be verified into factors of justice, welfare, concern for the people, and so on. This is the essence of law which is always in the process of becoming (law as a process, law in the making). The law does not exist for oneself, but the law is for the service of humans.

Although for the time being related to the determination of the suspect (including seizing and search) as a pretrial object, it is outside the provisions of Article 1 point 10 Jo. Article 77 of the Criminal Procedure Code has been accommodated by the Constitutional Court through its decision Number $21 /$ PUU-XII / 2014, dated 28 October 2014. However, the research results of the Supreme Court Kumdil Research and Development Agency in literature research on the Determination of Suspects "in October 2016, at the South Jakarta District Court and the Court Negeri Jakarta Timur between the period 2010 to 2015, in fact, concluded that:

1. Law Number 8 of 1981 concerning the Criminal Procedure Code (KUHAP) is still the main guideline in proceedings, especially in cases of the pretrial petition.

2. The pretrial object has been regulated in article 77 of the Criminal Procedure Code, which is then based on the decision of the Constitutional Court Number: 21 / PUU-XI1 / 2014 and the pre-trial decision on behalf of Budi Gunawan, the object has been expanded, namely, the Pretrial Judge has the authority to adjudicate regarding the Determination of Suspects against someone.

3. Constitutional Court decisions regarding Pretrial and Pretrial decisions on behalf of Budi Gunawan have not become a guideline for judges to examine and try Pretrial petitions.

To support that, between April and June 2020 researchers have also conducted research in 3 (three) Special Class IA District Courts (PN) which are barometers of law enforcement nationally, especially regarding the settlement of pretrial cases related to the determination of suspects as pretrial objects after the Constitutional Court decision No. 21 / PUU-XII / 2014, dated 28 October 2014, between 2016 and 2019, namely in PN. South Jakarta, PN.Jakarta Barat, and PN. Surabaya, because it must be acknowledged that the Pre-Trial Decision on behalf of Budi Gunawan [8] is a momentum for the suspects to get justice by filing pretrial litigation.
Although the regulations and/ or arrangements for the authority of judges in resolving pretrial due to the Constitutional Court decision Number 21 / PUUXI1 / 2014, dated 28 October 2014 have changed, the results of research conducted by researchers and the Supreme Court Kumdil (Research and Development Agency) prove that there are still many judges in Indonesia, which adheres to the formal provisions of Article 1 number 10 in conjunction with Article 77 of the Criminal Procedure Code and is not willing to follow the Constitutional Court decisions and the Pretrial decisions on behalf of Budi Gunawan, which expands the objects of the Pretrial Office, and therefore becomes a reason for researchers to unravel obstacles and seek solutions In order to realize the justice that the community desires, namely by reconstructing the regulation of the authority of judges in adjudicating pretrial applications, in order to realize law enforcement that contains substantive justice, not formal legal. Moreover, the development of the draft amendments to the Criminal Procedure Code drafted by the Government together with the DPR, especially those concerning pretrial obstacles related to the Preliminary Examination Judge (HPP) proposal was widely opposed by the Police and the Attorney General's Office, so in order to realize fair legal certainty in deciding the pretrial cases, For this reason, the reconstruction of regulations on the authority of judges in hearing pretrial applications can be carried out as has been explained must consider its effect in society as when laws are discussed in the legislature, all opinions are good and perfect. However, when it is promulgated, the law immediately confronts a thousand kinds of concrete problems that are beyond reach and unthinkable at the time of discussion and formulation.

This fact also occurred in the development of the Criminal Procedure Code in practice when the Constitutional Court, through its decision Number $21 /$ PUU-XI1 / 2014, dated 28 October 2014, changed the regulation on the meaning of preliminary evidence, sufficient initial evidence, and sufficient main evidence. In order to fulfill the principle of fair legal certainty as stipulated in Article 28 D paragraph (1) of the 1945 Constitution and comply with the lex certa and lex stricta principles in criminal law, the phrase "preliminary evidence," "sufficient initial evidence." and "sufficient main evidence," as stipulated in Article 1 point 14, Article 17, and Article 21 paragraph (1) of the Criminal Procedure Code must be interpreted by at least two pieces of evidence contained in Article 184 of the Criminal Procedure Code and accompanied by an examination of potential suspects.

Article 1 paragraph (3) of the 1945 DUD affirms that Indonesia is a constitutional state. In a constitutional state, the principle of "due process of law" as a manifestation of human rights recognition in the criminal justice process is a principle that must be upheld by all parties, especially for law-enforcing 
institutions [9]. This respect for human rights is realized by providing a balanced position based on applicable legal principles, including in the criminal justice process, especially for suspects, defendants, and convicts in defending their rights in a balanced manner. Therefore, the state, especially the Government, is obliged to provide protection, advancement, enforcement, and fulfillment of human rights (vide Article 28I paragraph (4) of the 1945 Constitution).

KUHAP as formal law in the criminal justice process in Indonesia has formulated a number of rights of suspects/ defendants as protection against possible violations of human rights. However, even though the principle of "due process of law" [10] as a manifestation of the recognition of human rights in the criminal justice process has been guaranteed by the Criminal Procedure Code, by seeing close attention, the correlation between the provisions of Article 1 point 10 in conjunction with Article 77 KUHAP which regulates authority The District Court to examine and decide according to a manner regulated by law, the rights of suspects to carry out pretrial examinations in order to assess the validity of the actions of law enforcers (investigators) in carrying out their duties and authorities, connected with the investigator's authority to carry out investigations in relation to the suspect as regulated in Article 7 paragraph (1) of the Criminal Procedure Code, it appears that there is no balance.

According to the provisions of Article 1 the number 10 jo. Article 77 of the Criminal Procedure Code, District Courts are only given the authority to examine and make decisions in ways regulated by law regarding a). Whether or not an arrest and or detention is legal at the request of the suspect or his family or other party or the suspect's attorney, b). whether or not the termination of investigation or prosecution is legal at the request for the sake of upholding law and justice, and c). A request for compensation or rehabilitation by the suspect or his family or other parties on his behalf whose case has not been filed in court. Meanwhile, on the other hand, Article 7 paragraph (1) of the Criminal Procedure Code by law on Investigators is given 10 (ten) authority where all of it intersects with human rights. Even up to the last point, the Investigators are given the authority to take other actions according to responsible law. If the imbalance between the suspect's rights to make corrections to the investigator's authority in conducting investigations as stated in the pretrial and the investigator's rights in conducting investigations are not immediately revised to be corrected so that a balance is created, then every time there is a suit against a new pretrial application against the object that has not been regulated in Article 1 point 10 in conjunction with Article 77 KUHAP jo. The Constitutional Court Decision No.21 / PUU-XII / 2015, and the judge's decision stated that the pretrial lawsuit was grounded and granted, undoubtedly the shock, commotion, and legal uncertainty in the settlement of pretrial cases will continue to occur and consequently have an impact on the realization of substantive justice which is the moral obligation of the judge to become constrained.

On the basis of the above reasons, the reconstruction of the regulation on the authority of judges in examining and deciding pretrial cases based on justice according to researchers must be done as follows:

a. adding one provision between letter b) and letter c) in Article 82 paragraph (1) of the Criminal Procedure Code and adding 2 (two) paragraph in Article 1 number 10 in conjunction with Article 77 KUHAP jo. The Decision of the Constitutional Court No.21 / PUU-XII / 2015, by means of reasoning or interpreting a contrario to the provisions of Article 1 point 10 jo. Article 77 KUHAP jo. The existing Constitutional Court Decision No.21 / PUU-XII / 2015.

b. Adding one provision between letter b) and letter c) in Article 82 paragraph (1) of the Criminal Procedure Code referred to here is to add the authority of the judge to examine the validity of the acquisition of evidence as well as its relevance to the subject matter of the alleged case.

As for reasoning or a contrario interpretation of the provisions of Article 1 point 10 in conjunction with Article 77 KUHAP jo. The existing Constitutional Court Decision No.21 / PUU-XII / 2015 were to add 2 (two) paragraphs, namely:

a. Legal or not the investigation. As a right granted to a suspect by taking a position contrary to the existing provisions of the law which gives investigators the authority to stop investigations at the initiative of the investigator.

b. Legal or no other actions according to responsible law. As a right granted to a suspect, he takes the opposite position from the provisions of the existing law which authorizes investigators to take other actions according to responsible law.

Whereas with the addition of the 2 (two) paragraphs mentioned above, according to the researcher, when the pretrial hearing is in process, it can then be proven that there is something wrong in the investigation process when a person is declared a suspect. Whereas by the 1945 Constitution everyone is guaranteed the right to get recognition, guarantee, protection, and legal certainty that is just and equal treatment before the law so it is solely for the sake of protecting someone from arbitrary actions by an investigator which is likely to occur when someone is named a suspect, even though in the process there is an error, since there are no other institutions other than pretrial institutions that can examine and decide the case as a horizontal supervisor of the District Court. 


\section{CONCLUSION}

1. Because the provisions of the Criminal Procedure Code that adhere to the principle of formal legality are not in sync when faced with an independent judicial power that is required to uphold law and justice based on Pancasila, the result is that even though the principles of basic provisions of judicial power have been used as guidelines, but because in deciding pretrial must be in the corridor the provisions of Article 3 of the Criminal Procedure Code, then no matter how good a pretrial judge's decision accommodates a sense of substantive justice, the result is considered by some legal experts as a decision that violates procedural law. And besides the inconsistency of the Criminal Procedure Code, on the one hand, it adheres to the accusatory principle, but on the other hand, the Criminal Procedure Code still gives discretion to investigators to take other actions according to the law that is responsible without clear boundaries that have the potential to harm the interests of the suspect. As a result, when a judge sees violations of human rights in the determination of a suspect, but because the pretrial object is outside the provisions of Article 1 number 10 jo Article 77 of the Criminal Procedure Code when the verdict declares the determination of the suspect invalid, the judge will still be considered to have violated the procedural law The independence and implementation of the judge's obligation in understanding and exploring the values that grow and live in society seem to convey him as a person he deems to have an interest. And this is the weakness of the judge's decision who tried the pretrial hearing from a justice perspective

2. Reconstruction of the regulation on the authority of judges in adjudicating justice-based pretrial applications according to the author can be realized by changing the SKB of the Chairman of the Supreme Court of the Republic of Indonesia and the Chair of the Indonesian Judiciary No.047 / KMA / SKB / IV / 2009 and 02 / SKB / P.KY / IV / 2009 by adding the phrase: "but while still encouraging judges to make legal discoveries responsibly in order to realize justice according to the values that live and grow in society", adding one provision between letter b) and letter c) in Article 82 paragraph (1) of the Criminal Procedure Code, namely give the judge authority to examine the validity of the acquisition of evidence and its relevance to the subject matter of the case being suspected. As well as adding 2 (two) paragraphs in
Article 1 point 10 in conjunction with Article 77 KUHAP jo. The Constitutional Court Decision No.21 / PUU-XII / 2015, by means of reasoning or interpreting a contrario to the provisions that already existed, namely: Whether an investigation is legal. As a right given to a suspect by taking a position contrary to the provisions of the existing law which gives the investigator the authority to stop investigations at the initiative of the investigator and whether other actions are legal according to responsible law As a right given to a suspect to take the opposite position from the provisions of the existing law which authorizes investigators to take other actions according to a responsible law..

\section{REFERENCES}

1. Hans, K., Indonesian Translated by B. Arief Sidharta. (2011). Hukum dan Logika, Alumi, Bandung.

2. Muladi. (2002). Demokratisasi, hak asasi manusia, dan reformasi hukum di Indonesia, Habibie Center, Jakarta.

3. Faisal. (2010). Menerobos Positivisme Hukum, Rangkang Education, Yogyakarta.

4. Johnny Ibrahim. (2005). Teori dan Metodologi Penelitian Hukum Normatif, Bayumedia, Surabaya.

5. Moleong, L. J. (2004). Metode Penelitian Kualitatif, PT. Remaja Rosdakarya: Bandung.

6. Widyastuti, Ida \& Dewi, Anak \& Sugiartha, I. (2020). Kewenangan Pengadilan Negeri Memutus Perkara Praperadilan Mengenai Tidak Sahnya Penetapan Tersangka. Jurnal Analogi Hukum. 2. 351-355. 10.22225/ah.2.3.2519.351-355.

7. Herlinda, H. (2019). Tinjauan Yuridis Terhadap Kewenangan Hakim Praperadilan Dalam Memustukan Permohonan Praperadilan Dengan Objek Menetapkan Tersangka. Badamai Law Journal. 4. 164. 10.32801/damai.v4i1.9235.

8. Mahkamah, Agung, R.I. (2016). Pengkajian Tentang Putusan Pra Peradilan (Laporan Penelitian), Pusat Penelitian dan Pengembangan Mahkamah Agung RI, Jakarta.

9. Widodo, W., Budoyo, S., \& Pratama, T. G. W. (2018). The role of law politics on creating good governance and clean governance for a freecorruption Indonesia in 2030. The Social Sciences, 13(8), 1307-1311.

10. Kusuma, I. M. W. W., \& Karma, N. M. S. (2020). Upaya Hukum Praperadilan dalam Sistem Peradilan Pidana di Indonesia. Jurnal Interpretasi Hukum, 1(2), 73-77. 